Global Cooperation Among G20 Countries 
Michael Callaghan $•$ Chetan Ghate

Stephen Pickford $\bullet$ Francis Xavier Rathinam

Editors

\section{Global Cooperation Among G20 Countries}

Responding to the Crisis and Restoring Growth

囪 Springer 


\section{Editors}

Michael Callaghan

G20 Studies Center

Lowy Institute for International Policy

Sydney

Australia

\section{Chetan Ghate}

Economics and Planning Unit

Indian Statistical Institute-Delhi

New Delhi

India

\author{
Stephen Pickford \\ Chatham House \\ London \\ United Kingdom
}

Francis Xavier Rathinam

South Asia Research Hub

Department for International

Development (DFID)

New Delhi

India

ISBN 978-81-322-1658-2

ISBN 978-81-322-1659-9 (eBook)

DOI 10.1007/978-81-322-1659-9

Springer New Delhi Dordrecht Heidelberg London New York

Library of Congress Control Number: 2013955068

\section{(C) Springer India 2014}

This work is subject to copyright. All rights are reserved by the Publisher, whether the whole or part of the material is concerned, specifically the rights of translation, reprinting, reuse of illustrations, recitation, broadcasting, reproduction on microfilms or in any other physical way, and transmission or information storage and retrieval, electronic adaptation, computer software, or by similar or dissimilar methodology now known or hereafter developed. Exempted from this legal reservation are brief excerpts in connection with reviews or scholarly analysis or material supplied specifically for the purpose of being entered and executed on a computer system, for exclusive use by the purchaser of the work. Duplication of this publication or parts thereof is permitted only under the provisions of the Copyright Law of the Publisher's location, in its current version, and permission for use must always be obtained from Springer. Permissions for use may be obtained through RightsLink at the Copyright Clearance Center. Violations are liable to prosecution under the respective Copyright Law.

The use of general descriptive names, registered names, trademarks, service marks, etc. in this publication does not imply, even in the absence of a specific statement, that such names are exempt from the relevant protective laws and regulations and therefore free for general use.

While the advice and information in this book are believed to be true and accurate at the date of publication, neither the authors nor the editors nor the publisher can accept any legal responsibility for any errors or omissions that may be made. The publisher makes no warranty, express or implied, with respect to the material contained herein.

Printed on acid-free paper

Springer is part of Springer Science+Business Media (www.springer.com) 


\section{Contents}

Global Cooperation Among G20 Countries: Responding to the

Crisis and Restoring Growth

Michael Callaghan, Chetan Ghate, Stephen Pickford and

Francis Rathinam

The G20 Since 2008: Some Reflections on the Experience and the Road Ahead

Subir Gokarn

Part I Eurozone Crisis: Short-Run Challenges and Options

Overcoming the Euro Area Crisis-Reforms and Results

Holger Fabig, Yannick Kirchhof and Inka Zippe

Predicting the Euro: A Practitioner's Perspective

Abheek Barua

Monetary Integration in Europe and the Drawbacks of

Centralization

Heribert Dieter

Reflections on the Euro Crisis.

Pierre Jacquet

\section{Part II Rebalancing the Global Economy}

The G20, IMF and Global Imbalances: The Policymakers' Perspective

Michael Callaghan

Global Imbalances: Causes and Policies to Address Them

Emil Stavrev 
Exchange Rate Flexibility and Economic Rebalancing in China

Takuji Kinkyo

Global Imbalances and Financial Fragility

Jong Kook Shin and Chetan Subramanian

\section{Part III Financial Sector Regulation}

Financial Regulatory Reforms: Not Far Enough, or Too Far?

Stephen Pickford

Asian Perspectives for Financial Regulatory Reforms after the

Asian Financial Crisis

Jae-Ha Park

The Challenge of Financial Stability and Regulation from a

European Perspective

Paul Bernd Spahn

Financial Regulatory Reforms: Striking a Balance.

Anand Sinha

Part IV A New Framework for Reforming the International Monetary System

Reforming the International Monetary System: an Institutional

Perspective

Jyoti Rahman, Ewa Orzechowska-Fischer and Redom Syed

Strengthening the International Monetary System

Emil Stavrev

Systemic Sudden Stop(s), Credit Lines, and Funding Liquidity

Gurbachan Singh

Part V Capital Control Policy and Emerging Market Economies (EMEs)

Policy Trade-offs in an Open Economy and the Role of G20 in

Global Macroeconomic Policy Coordination

Rajeswari Sengupta and Abhijit Sen Gupta

Managing the Risks Associated with Volatile Capital Flows

Atish R. Ghosh

On an Asian Monetary Union: What does the Evidence Tell us? David Kim 
Part VI Austerity and Growth

The Macroeconomic Policy Response to the International

Financial and Economic Crisis and the G20

Alok Sheel

Austerity, Growth, and Public Policy.

Denis Medvedev and Smriti Seth

India and Fiscal Austerity

Shankar Acharya

Erratum

Index 


\title{
Contributors
}

Shankar Acharya Honorary Professor, Indian Council for Research on International Economic Relation (ICRIER), and former Chief Economic Adviser to the Government of India

\begin{abstract}
Abheek Barua Chief Economist, HDFC Bank, India
Michael Callaghan Director, G20 Studies Centre, Lowy Institute for International Policy, Sydney, Australia
\end{abstract}

Heribert Dieter Senior Associate, German Institute for International and Security Affairs (SWP), Berlin, Germany

Visiting Professor, Zeppelin University, Friedrichshafen, Germany

Holger Fabig Head of Division, G7/G8, G 20, World Economy, Currency Issues, Ministry of Finance, Berlin, Germany

Ewa Orzechowska-Fischer Analyst, International Finance and Development Division, Department of Treasury, Canberra, Australia

Chetan Ghate Indian Statistical Institute-Delhi, New Delhi, India

Atish R. Ghosh Chief, Systemic Issues and Assistant Director, Research Department, International Monetary Fund, Washington DC, USA

Subir Gokarn Director of Research, Brookings India, New Delhi, India Former Deputy Governor, Reserve Bank of India, New Delhi, India

Abhijit Sen Gupta Senior Economics Officer, India Resident Mission, Asian Development Bank, New Delhi, India

Pierre Jacquet President, Global Development Network, Washington DC, USA

David Kim Senior Lecturer, School of Economics, University of Sydney, Australia

Takuji Kinkyo Professor of Economics, Kobe University, Kobe, Japan

Yannick Kirchhof Economist, Ministry of Finance, Berlin, Germany 
Denis Medvedev Senior Country Economist, Economic Policy and Poverty unit, The World Bank, New Delhi, India

Jae-Ha Park Deputy Dean, Asian Development Bank Institute, Tokyo, Japan

Stephen Pickford Senior Research Fellow, International Economics, Chatham House, London, UK

Jyoti Rahman Manager, International Finance and Development Division, Department of Treasury, Canberra, Australia

Francis Rathinam Department for International Development (DFID), New Delhi, India

Smriti Seth Research Analyst, Economic Policy and Poverty unit, The World Bank, New Delhi, India

Rajeswari Sengupta Assistant Professor of Economics, The Institute for Financial Management and Research (IFMR), Chennai, India

Alok Sheel Secretary, Economic Advisory Council to Prime Minister of India, New Delhi, India

Jong Kook Shin Lecturer, Queen's University Management School, Queen's University, Belfast, Northern Ireland, UK

Gurbachan Singh Independent Researcher, and Visiting Faculty, Economics and Planning Unit, Indian Statistical Institute-Delhi, New Delhi, India

Anand Sinha Deputy Governor, Reserve Bank of India, Mumbai, India

Paul Bernd Spahn Professor Emeritus, Goethe University, Frankfurt am Main, Germany

Emil Stavrev Deputy Division Chief, Multilateral Surveillance Division

Research Department, International Monetary Fund, Washington DC, USA

Chetan Subramanian Associate Professor, Department of Economics, Indian Institute of Management Bangalore, Bengaluru, India

Redom Syed Analyst, International Finance and Development Division, Department of Treasury, Canberra, Australia

Inka Zippe Intern, Ministry of Finance, Berlin, Germany 


\section{About the Editors}

Michael Callaghan is Director of the G20 Studies Centre at the Lowy Institute for International Policy. Mike has extensive experience on international economic issues, both in the Australian Treasury and the International Monetary Fund (IMF). From 2008 until 2012 he was Executive Director (International) in the Treasury and was Australia's G20 Finance Deputy. Mike also served as the Prime Minister's Special Envoy, International Economy. From 2005 until 2007 he was Executive Director, Revenue Group in the Treasury. Prior to this position he spent four years at the IMF in Washington DC as an Executive Director. Between 1999 and 2000, Mike served as Chief of Staff to the Australian Treasurer, the Hon Peter Costello. Mike has held various senior positions in the Australian Treasury. In 2009 he was awarded the Public Service Medal and in 2013 was made a Member of the Order of Australia.

Chetan Ghate is Associate Professor in the Economics and Planning Unit of the Indian Statistical Institute - Delhi. He is currently a member of the Technical Advisory Committee for Monetary Policy at the Reserve Bank of India. He received his Ph.D. in Economics and M.S. in Applied Mathematics from Claremont Graduate University (USA); Masters in Economics from the Delhi School of Economics (India); and B.A. Economics from Colorado College (USA). He has held faculty positions at the Colorado College, the German Institute of Economic Research, University of Sydney, and Claremont Graduate University. His areas of interest lie in macroeconomic theory and policy. He has published in several leading journals in his field. He recently edited "The Oxford Handbook of the Indian Economy" (OUP) which was selected as one of CHOICE's "Outstanding Academic Titles for 2012". In May 2011, he was a recipient of a Rockefeller Foundation residency in Bellagio, Italy. From 2012-2013 he was the Reserve Bank of India Chair Professor in Macroeconomics at ICRIER (New Delhi).

Stephen Pickford is Senior Research Fellow at Chatham House in London, UK. He has worked on international economic issues for much of his career, and retired from HM Treasury (UK) in 2010, where he was the Managing Director (International and Finance) and the UK's G7 and G20 Finance Deputy. Prior to this he held posts dealing with both European and international finance issues at HM Treasury, 
and from 1998 to 2001 he was the UK's Executive Director on the boards of the IMF and World Bank. Previous positions included leading the team responsible for Bank of England independence in 1997, and between 1989 and 1993 he worked on macroeconomic policy and forecasting at the New Zealand Treasury. He was educated at the University of Cambridge, England and the University of British Columbia, Canada.

Dr. Rathinam is a research advisor with the Department for International Development (DFID). His recent research work explores the legal, regulatory and political economy aspects of current financial and banking sector reforms in India. Formerly he was a senior fellow at ICRIER. He has a Ph.D. in Economics from Hyderabad Central University and was a visiting fellow at the Institute for Law and Economics, University of Hamburg, Germany. Dr. Rathinam has published in Emerging Markets Review, Macroeconomics and Finance in Emerging Market Economies, Environment and Development Economics, among others. 


\title{
Abbreviations and Acronyms
}

\author{
CQS Calculated quota share \\ EMDC Emerging market and developing countries \\ EU European Union \\ FCL Flexible credit line \\ G20 Group of twenty \\ G7 Group of seven \\ GDP Gross domestic product \\ GFC Global financial crisis \\ IEO Independent Evaluation Office \\ IMF International Monetary Fund \\ IMS International monetary system \\ NAB New Arrangements to Borrow \\ PCL Precautionary credit line \\ PPP Purchasing power parity \\ RFA Regional financing arrangements \\ US United States \\ WTO World Trade Organisation
}

